\title{
What we may learn - and need - from pandemic fiction
}

\author{
Jane Doherty and James Giordano*
}

\author{
Abstract \\ N/A \\ Keywords: Science fiction, Pandemic, Cognition, COVID-19, SARS-CoV2
}

During this pandemic, many have found themselves glued to the news searching for a better understanding of the current situation. People are desperate for factual information to either assuage or verify their fears. This sentiment is exemplified in the very nomenclature of the abundant programs covering COVID-19 [1]. But this begs the questions: does fact always trump fiction? And, are they actually at odds with one another?

First, it's important to understand that fiction is not the same as a lie [2, 3]. To be sure, facts trump lies. While both deal with the unreal, a lie is intentionally opposed to some truth, whereas fiction intends to provide an illustration - albeit through implicit meanings and conclusions - of reality. Since the global outbreak of COVID-19, internet users' interest in movies about pandemics has increased by $4900 \%$ [4]. The timing and the magnitude of this increased interest makes clear that science fiction stories offer more than simply entertainment. Instead, people may be engaging with movies like Contagion [5], Outbreak [6], The Andromeda Strain [7], Flu [8], and Virus [9] in ways similar to those reasons for which they turn to the news: a desire and search for deeper understanding and some sense of security from things unknown.

Literary enthusiast Patrick Parrinder describes science fiction as a "thinking machine" that provides an outlet to

\footnotetext{
* Correspondence: james.giordano@georgetown.edu

Departments of Neurology and Biochemistry, and Pellegrino Center for Clinical Bioethics, Georgetown University Medical Center, Washington DC, USA
}

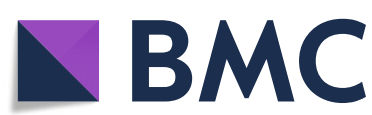

(c) The Author(s). 2020 Open Access This article is licensed under a Creative Commons Attribution 4.0 International License, which permits use, sharing, adaptation, distribution and reproduction in any medium or format, as long as you give appropriate credit to the original author(s) and the source, provide a link to the Creative Commons licence, and indicate if changes were made. The images or other third party material in this article are included in the article's Creative Commons. licence, unless indicated otherwise in a credit line to the material. If material is not included in the article's Creative Commons licence and your intended use is not permitted by statutory regulation or exceeds the permitted use, you will need to obtain permission directly from the copyright holder. To view a copy of this licence, visit http://creativecommons.org/licenses/by/4.0/ The Creative Commons Public Domain Dedication waiver (http://creativecommons.org/publicdomain/zero/1.0/) applies to the data made available in this article, unless otherwise stated in a credit line to the data.

\section{How does fear influence us?}

Fear is central to any portrayal of a pandemic. These movies allow viewers to more carefully examine the basis, uses, and pitfalls of fear. For example, in the film Outbreak [6], Dustin Hoffman's character states that "fear gets a bad rap." When things are truly scary, fear serves as a reminder of human vulnerability. In this way, fear is akin to a litmus test, indicating what we truly care about, dread losing, and want to protect. But fears are not always based in reality, and such misapprehension can be counterproductive. The films Contagion [5] and Flu [8] get audiences to question the source of fear, and 
recognize the danger of misinformation. This is accomplished through dialogue such as "... in order to become sick, you first need to come in contact with the disease. In order to get scared, all you have to do is come in contact with a rumor ... spreading [rumors] is far more dangerous than the disease" [5]. Fiction enables us to examine our fears and sources of information about COVID-19.

\section{Who do we turn to for answers?}

A consistent plot line in almost all pandemic fiction involves a struggle for authority between a scientist and a politician. Pandemic movies depict the pendulum of peoples' trust in scientists: swinging from a belief that scientists are "Jesus in a lab coat", to a complete lack of confidence, if not outright disdain [5]. Ultimately, through plot resolution, these conflicting views are smoothed. Pandemic movies teach that these problems cannot be solved without science, and in so doing compel us to strengthen appropriately balanced collaboration between scientists and other authority figures.

\section{In a world where many are suffering, who gets treatment?}

With mass infection, these fictitious worlds' resources are stretched thin, raising the ethical dilemma of how to distribute the limited aid available. As recent headlines have revealed, life and art are not so distinct. Pandemic movies expose the impact that our urge to protect loved ones can have on the equity of resource distribution. This turns the lens of film into a mirror upon our own values, and the ways that we regard self, kin, kith, and others. The characters in Outbreak [6], Contagion [5], and Flu [8] are compelled to treat either themselves, their families, or "their own people" first. But as so well expressed in Contagion, "... we all have people" [5]. These storylines encourage us to question who we consider in- and/or out-groups, and prompt us to query such distinctions in order to ethically care for and treat humanity at-large.

The "thinking machine" that is pandemic science fiction evokes intentional reflection on these pertinent questions. But what if these fictional portrayals of pandemics are doing more to help comprehend this crisis and how we think and behave in response? Neuroscientific investigations of imagination and visualization reveal how fiction might affect thought processes in more subtle ways [12-17]. Fiction, long cherished for its ability to transport its audience to different worlds and into the minds of characters [18], is highly dependent upon the brain's capacity for visualization. Visualization is the mental exercise of imagining what is not depicted in our local reality [19]. Several studies have linked the practice of visualizing to cognitive functions beyond the mere ability to enjoy a story. They demonstrate that the act of mental simulation or visualization increases the likelihood of believing the visualized events will occur in the future [14], can aid emotional regulation and emotional coping, and improve problem-solving and planning capabilities [12].

A Harvard University study [14] showed that thinking about an emotion engages the same neurological networks as talking about and feeling one's actual emotions. For sure, COVID-19 has imposed new emotional strains [20]. Thus, it is possible that mentally stimulating or viewing these emotions - via film - could be a form of coping that leads to greater emotional regulation. So, it seems that viruses aren't the only contagious thing being depicted in pandemic movies: emotions can be "transferred" from the screen to our brains just as quickly as the fictional disease spreads from one character to another. When we watch pandemic fiction, we are mentally rehearsing the range of emotions being depicted in these films. Common throughout all are feelings of fear, confusion, desperation, and isolation - a simulacrum of those currently so prevalent. By dealing with these emotions through fiction, the imagination involved may help us process our intense feelings and afford capabilities to better navigate these tumultuous times.

A UCLA study, Harnessing the Imagination, revealed that problem-solving skills improved when participants used specific visualization techniques [12]. To be effective, visualization had to involve mentally engaging in steps that individual participants thought were necessary to accomplish their goals. Simply picturing some magical solution to their problem was ineffective. This need for realism is further supported by the work of Daniel Kahneman and Dave Miller who observed that to be productive, visualization ought "not to rely on improbable or fantastic steps along the way" [21].

Applying this outcome of visualization - improved problem-solving and planning skills - to the experience of mentally processing a science fiction storyline can get a little murky. Could making pandemic movies follow more realistic, scientifically-informed plots improve our ability to plan for the future? Further research is needed to examine whether watching the problem-solving process portrayed in a movie provides equivalent benefits to mentally rehearsing the goal-productive steps as demonstrated in the UCLA study [12] Perhaps the impetus for such studies lies in scientifically exploring the validity of the sentiment that "you become what you think about all day long" [22].

Of course, science fiction is allowed, if not required, to break the rules of what is true, and wander into the realm of the unreal. Let's not forget that the unfamiliar is what makes fiction so powerful and appealing. While acknowledging that science fiction is entitled to breaches 
in reality, we should keep in mind the intricate interdependence of fiction and fact. When science fiction is used as a tool to grapple with current realities - as exemplified by the resurgent popularity of pandemic movies the genre takes on an additional obligation: to honor, and positively leverage, the reciprocity between works of fiction and our perception of fact. By creating stories that are rooted in scientific fact and that retain cultural relevance, we can maximize science fiction's positive impact on our real-world response to this pandemic. In this way, fact-informed fiction can lead us to engage in more meaningful reflection of stories' object lessons and through them, build a better fiction-informed future.

\section{Acknowledgements}

The authors thank Sherry Loveless for technical support in the preparation and submission of the manuscript.

\section{Authors' contributions}

Both authors developed, wrote, and approved the content of this manuscript.

\section{Funding}

This work was supported in part by the Henry Jackson Foundation (JG); and Leadership Initiatives (JG).

\section{Availability of data and materials \\ N/A}

\section{Ethics approval and consent to participate}

N/A

\section{Consent for publication}

N/A

\section{Competing interests}

The authors do not have any conflicts of interest.

Published online: 21 July 2020

\section{References}

1. CNN. Coronavirus: Fact vs Fiction. https://www.cnn.com/audio/podcasts/ corona-virus. Accessed 7 June 2020.

2. Holland DC, Quinn N, editors. Cultural models in language and thought. Cambridge [Cambridgeshire]: Cambridge University Press; 1987. p. 400.

3. Meibauer J, editor. The Oxford handbook of lying. 1st ed. Oxford: Oxford University Press; 2019.

4. Pandemic Movies - Google Trends. https://trends.google.com/trends/ explore?q=pandemic\%20fiction. Accessed 15 June 2020.

5. Soderbergh S. Contagion. Motion Picture. Shamberg M, Sher S, Jacobs G, producers. United States: Warner Bros. Entertainment; 2011.

6. Petersen W. Outbreak. Motion picture. Katz G, Kopelson A, Kopelson A, Petersen W, producers. United States: Warner Bros; 1995.

7. Wise R. Andromeda strain. Motion picture. Wise R, producer. United States: Universal Pictures; 1971

8. Kim S. Flu. Motion Picture. Kim S, Seo J, Jeong H, Yeong-jong I, producers. South Korea: CJ Entertainment; 2013.

9. Abu A. Virus. Motion Picture. Abu A, producer. India: OPM Cinemas; 2019.

10. Parrinder P. Science fiction: its criticism and teaching. London: Metheun; 1980. p. 166. New accents.

11. van den Oever A, editor. Ostrannenie: on "strangeness" and the moving image: the history, reception, and relevance of a concept. Amsterdam: Amsterdam University Press; 2010. p. 278. The key debates.

12. Taylor SE, Pham LB, Rivkin ID, Armor DA. Harnessing the imagination: mental simulation, self-regulation, and coping. Am Psychol. 1998;53(4):429-39.

13. Schacter DL, Addis DR, Buckner RL. Episodic simulation of future events: concepts, data, and applications. Ann N Y Acad Sci. 2008;1124(1):39-60.
14. Koehler DJ. Explanation, imagination, and confidence in judgment. Psychol Bull. 1991:110(3):499-519.

15. Johnson-Laird PN. Mental models: towards a cognitive science of language, inference, and consciousness. 6. Print. Cambridge: Harvard University Press; 1995. p. 513. Cognitive science series.

16. Oatley K. Why fiction may be twice as true as fact: fiction as cognitive and emotional simulation. Rev Gen Psychol. 1999;3(2):101-17.

17. Mar RA, Oatley $K$. The function of fiction is the abstraction and simulation of social experience. Perspect Psychol Sci. 2008;3(3):173-92.

18. Green MC, Brock TC. The role of transportation in the persuasiveness of public narratives. J Pers Soc Psychol. 2000;79(5):701-21.

19. Thomas NJT. Mental imagery. 1997; Available from: https://plato.stanford. edu/archives/sum2019/entries/mental-imagery/ [cited 2020 Jun 12]

20. Mazza C, Ricci E, Biondi S, Colasanti M, Ferracuti S, Napoli C, et al. A nationwide survey of psychological distress among italian people during the covid-19 pandemic: immediate psychological responses and associated factors. IJERPH. 2020;17(9):3165.

21. Kahneman D, Miller DT. Norm theory: comparing reality to its alternatives. Psychol Rev. 1986;93(2):136-53.

22. GoodReads. A Quote by Ralph Waldo Emerson. https://www.goodreads. com/quotes/114540-you-become-what-you-think-about-all-day-long. Accessed 7 June 2020

\section{Publisher's Note}

Springer Nature remains neutral with regard to jurisdictional claims in published maps and institutional affiliations.

\section{Ready to submit your research? Choose BMC and benefit from:}

- fast, convenient online submission

- thorough peer review by experienced researchers in your field

- rapid publication on acceptance

- support for research data, including large and complex data types

- gold Open Access which fosters wider collaboration and increased citations

- maximum visibility for your research: over $100 \mathrm{M}$ website views per year

At $\mathrm{BMC}$, research is always in progress.

Learn more biomedcentral.com/submissions 